\title{
Book Review: Before the Line. Vol I, II, and III
}

Timothy K. Perttula

Heritage Research Center, Stephen F. Austin State University

Follow this and additional works at: https://scholarworks.sfasu.edu/ita

Part of the American Material Culture Commons, Archaeological Anthropology Commons, Environmental Studies Commons, Other American Studies Commons, Other Arts and Humanities Commons, Other History of Art, Architecture, and Archaeology Commons, and the United States History Commons

Tell us how this article helped you.

This Article is brought to you for free and open access by the Center for Regional Heritage Research at SFA ScholarWorks. It has been accepted for inclusion in Index of Texas Archaeology: Open Access Gray Literature from the Lone Star State by an authorized editor of SFA ScholarWorks. For more information, please contact cdsscholarworks@sfasu.edu. 


\section{Book Review: Before the Line. Vol I, II, and III}

Creative Commons License

(c) (i) (8)

This work is licensed under a Creative Commons Attribution-NonCommercial 4.0 International License 


\section{BOOK REVIEW}

\section{Timothy K. Perttula}

Jim Tiller, Before the Line. Vol. I, An Annotated Atlas of International Boundaries and Republic of Texas Administrative Units Along the Sabine River-Caddo Lake Borderland, 1803-1841, xii +123 pp. The START Group, Huntsville, Texas, 2010.

Jim Tiller, Before the Line. Vol. II, Letters from the Red River, 1809-1842, xx + 353 pp. The START Group, Huntsville, Texas, 2012.

Jim Tiller, Before the Line. Vol. III, Caddo Indians: The Final Years, xii + 189 pp. The START Group, Huntsville, Texas, 2013.

This three volume set written and compiled by Dr. Jim Tiller of Sam Houston State University (Huntsville, Texas) represents a significant body of work concerning the history of East Texas-Northwest Louisiana between 1803-1842. His study area includes what is now Caddo Parish in Louisiana and Harrison and Panola counties in Texas. Tiller's interest in the history of the Caddo Indian peoples in this area is also shown by a series of articles he has written about them in recent years (Tiller 2007, 2008, 2010, 2011, 2013; Tiller and Gong 2012).

In Volume I of the set, Tiller looks at the Sabine River-Caddo Lake Area from 1803-1841 as an aspect of the early boundary history between Spain, Mexico, the Republic of Texas, and the United States/Louisiana. His goal is "to present and analyze from a geographical perspective the very considerable, but relatively little known, records that exist with regard to boundaries and administrative units" (Vol. I, p. x) of the Sabine RiverCaddo Lake borderland. In Part I of the volume, the many international boundaries in this region are reviewed and discussed, along with many excellent maps illustrating the shifting and conflicting boundaries. Tiller makes clear that there were a number of Caddo villages in this borderland area (Vol. I, pp. 4-5). His discussion of boundary history begins with the 1806 survey of the northern portion of the Neutral Ground, followed by the 1812 Pichardo d'Anville line, the William Darby Line of 1812, William Darby's map of 1816, Teran's Line of 1828, mid-1830s Mexican surveys, American survey activities between 1837-1838, and the Joint Boundary Commission survey of 1840-1841 that set the final boundary between Texas and the United States. Amidst these various efforts of boundary delineation, the Caddo Indian peoples found their traditional homelands increasingly coveted and claimed by American settlers, and on July 1, 1835, the Caddo Nation signed a treaty with the United States to cede their lands along the Red River and Caddo Lake (in what is now Northwest Louisiana and a small part of Southwest Arkansas, see Figure 1.32 in this volume; Vol. II of this compilation has many letters and pieces of correspondence concerning the treaty and its aftermath for the Caddo peoples).

Part II of Volume I takes up the administrative records that are part of the early (late 1830s and early 1840s) history of Harrison County in the Republic of Texas. Here, Tiller examines the establishment of land offices and districts as well as the evolution of county boundaries, as Harrison County was created in 1839 (Vol. I, p. 81); its boundaries were redefined in 1841. Tiller also notes that the Caddo remained in their villages (many of which were in what became Harrison County) along the unsettled boundary between the United States and Texas until March 1838, "continuing violence and related difficulties with area Whites, and the 
movement of American surveyors ... all combined to force the removal of the Caddo from their Sabine RiverCross Lake borderland villages west to the Cross Timbers and prairies of frontier Texas. In every instance, American surveyors noted in their early spring survey field notes that Caddo village sites in the area were either abandoned, deserted or in ruins" (Vol. I, p. 80).

Volume II will be of considerable interest to any historian or archeologist concerned with the study of the period from 1809-1842 in the northwestern Louisiana and northeastern Texas regions. In addition to a series of ca. 1804 to 1838 maps of the region, including an 1838 Township and Range map that shows the location of Dehahuit's Caddo village, Tiller has provided an invaluable service by including transcripts of letters in the National Archives and Records Administration, National Archives Microfilm Publications from the Letterbook of the Natchitoches-Sulphur Fork Factory, 1809-1821, and Letters Received by the Office of Indian Affairs, 1824-1881. In the case of the latter, the letters provided here concern the Red River Agency, 1824-1830 and the Caddo Agency, 1824-1842. These letters are packed with information (i.e., specific goods, costs, and tribal preferences and needs) about the Indian trade, more specifically the trade carried out between American factories and agencies and the Caddo peoples, as well as letters concerning relationships between the Americans and the Caddo tribes, especially regarding the difficulties faced by the Caddo because of illegal American settlement, whiskey traders, Texan depredations, and the deceit of their duly appointed U.S. Indian agents, especially Jehiel Brooks.

As examples of the contents of the letters, there are yearly lists of the wide range of trade goods to be made available at the U.S. trading factories in return for animal hides and furs (i.e., deer, beaver, otter, raccoon, foxes, and bear) bear oil, and other commodities provided by the Caddo peoples and other tribes that had moved into traditional Caddo homelands. These included clothing and linens, guns, gun locks, rifles, gun flints, and powder, as well as kettles, axes, knives, pairs of ear lobes (i.e., silver ear rings), and vermillion (Vol. II, pp. 13-14, pp. 67-68, p. 95). There are also testimonials and letters from the Caddo leaders proclaiming their loyalties to the Americans, or else protestations of poor treatments at the hands of various Americans and Texans (among them a May 28, 1831 letter from Dehahuit, Chief of the Caddo Nation to Andrew Jackson, President of the United States, Vol. II, p. 213): "That though his tribe had never shed the blood of a White many, yet his heart [the Caddo chief's) and hand had always been with us since he had first known us and that he was ready and willing to make common cause with us and that our enemies should be his enemies" (Letter from Thomas M. Linnard, Factor at the Natchitoches Trading House, September 6, 1813, Vol. II, p. 33), or "I had a good deal of conversation with the chiefs. They complained with too much truth of the Whites bringing whiskey among them and hunting on their grounds, etc." (Letter from John Fowler, Factor at the Natchitoches Trading House, May 9, 1817, Vol. II, pp. 60). One of the more interesting letters is an October 1, 1824 letter by George Gray, Indian agent at the Red River Indian Agency on the Sulphur Fork) that lists the 13 different Indian tribes living near the Red River Indian Agency, and their populations, including the Caddo (200 men and 250 women), Coushatta (80 men and 100 women), Choctaw (84 men and 94 women), and the Pascagoula (50 men and 71 women) (Vol. II, p. 110).

Also in these letters are statements by Americans conveying their respect for the Caddo Nation, even as they are dismayed at the lawlessness of the Americans increasingly in their midst. John Fowler, the Factor at the Natchitoches Trading House, had this to say about the Caddo peoples: "The Caddo in the neighborhood of this place are the oldest tribe in this country and are looked up to with a degree of reverence by all the Indians on Red River. They claim the land on both sides of Red River and on the right bank for 70 miles above me" (Letter of August 10, 1818, Vol. II, pp. 79). Tarshar, the Chief of the Caddo Nation, noted in an 1835 testimonial to President Andrew Jackson that "our traditions inform us that our villages have been established where they now stand ever since the first Caddo was created" (Vol. II, p. 246). 
In the last and most ambitious volume in the compilation, Tiller has two main concerns from a geographic perspective: (1) to consider the early $19^{\text {th }}$ century settlements of the Caddo (i.e., the Kadohadacho) in the Sodo Lakes region of Northwest Louisiana and East Texas; the East Texas Hasinai tribes are not the subject of this compendium, and (2) to review the 1835 Caddo land cession and its immediate aftermath (ca. 1835-1840), and the history of the Caddo peoples that returned and remained the region (most notably the Shreveport band) after 1838 under very difficult circumstances.

Part I of Vol. III concerns the early $19^{\text {th }}$ century Caddo settlements in the Sodo Lake region. Here, Tiller successfully employs the available historical and geographic records to identify and locate in space a number of long-forgotten and overlooked Caddo villages; the maps accompanying the text are excellent. He notes that these sites have been lost to history (p. 5), but fortunately, they may well yet be found in the archeological record. These sites include several north of the Sodo Lakes complex: a Caddo-Coushatta village at Cedar Bluff on the Red River, Sewell's Floodplain village, and the Jim's Bayou village (Ch. 3 in Vol. III reviews in great detail the question of whether this village was Timber Hill or the last Caddo settlement in the region). Tiller also identifies a number of early $19^{\text {th }}$ century Caddo settlements south of the Sodo Lakes complex, and suggests that this area was the principal focus of Caddo settlements after ca. 1800 in the East Texas-Northwest Louisiana borderlands. These villages include Dehahuit's village, the North Caddo village, the Middle Caddo village, the Big Spring Caddo village, Charles Sewell's Caddo village, and Col. Many's Caddo village. The latter two villages date to the latter part of 1838, and are associated with the Shreveport band of the Caddo. The other Caddo villages were abandoned and destroyed early in 1838. There are several other probable or possible early $19^{\text {th }}$ century Caddo settlements that Tiller has gleaned information about in the historical record, namely what he terms the Border village, the Louisiana village, an April 1838 Small village, and the Moooringsport Prairie village.

Chapters 2 and 3 in Vol. III provide more details on the interpretations offered by Tiller concerning the location of Dehahuit's village and the Caddo site on Jim's Bayou that he believes is not Timber Hill or the last Caddo settlement in East Texas. In the case of Dehahuit's village, in Chapter 2, using a variety of sources, he makes an effective argument that this site, likely occupied by the Caddo between ca. 1800 and early 1838, and their principal village at that time, is on Paw Paw Bayou on the old Natchitoches-Pecan Point (on the Red River) road, a few miles west of the Cross Lake part of the Sodo Lakes complex. Particularly effective is a scaled map overlay (Vol. III, Figure 2.9) of an 1807 map by Father Jose Puelles onto a modern map of the border area that nicely places both Caddo (Dehahuit's village) and Nadaco Caddo villages in accurate relationship to one another. Tiller then goes on to consider a Caddo village shown on William Darby's 1816 map of Louisiana, and concludes that this village is not the site on Jim's Bayou, nor is it the site of Dehahuit's village, but is instead a yet to be discovered early $19^{\text {th }}$ century Caddo settlement near the western end of Caddo Lake (Vol. III, p. 45).

The case of Timber Hill and the Jim's Bayou village is laid out in Chapter 3 of Vol. III. Tiller emphatically disputes the conclusions offered by Parsons et al. (2002a, 2002b) that site 41MR211 on James Bayou, north and west of the Sodo Lakes complex, "was Timber Hill; that it was the home of Dehahuit; and that it was the last Caddo village in their traditional East Texas-northwestern Louisiana homeland" (Vol. III, p. 47). In fact, he thoroughly castigates the archival research offered in Parsons et al. (2002a, 2002b), and suggests that it "was seriously lacking in terms of its thoroughness and analysis" and that "much of the readily available archival evidence related to the existence of such villages [Caddo villages south of the Sodo Lakes complex] seems to have been overlooked, misrepresented, or worse, ignored" (Vol. III, p. 55). Harsh words, indeed. Tiller's own sound geographical analysis leads him to the conclusion that the Jim's Bayou village known as 41MR211 was abandoned by 1830, and was not Timber Hill or Dehahuit's village. 
Tiller even goes so far as to suggest that 41MR211 is not a Caddo site: " . . while the record may suggest the Jim's Bayou settlement was a Caddo site, there is absolutely nothing in the record I am aware of that categorically [emphasis in original] defines the site as such" (Vol. III, p. 55). While there may be nothing in the historical record that indicates that 41MR211 is a Caddo site, there is no question from the material culture record, in particular the almost 400 sherds of Caddo ceramic vessels, recovered in the excavations (not survey, as Tiller describes it, Vol. III, p. 53) of 41MR211 that it is a Caddo site, and one occupied in the early $19^{\text {th }}$ century. Was the site abandoned by 1830 , as this is one tenet of Tiller's position that the site is not Timber Hill or Dehahuit's village? There are several lines of evidence in the artifacts recovered from the 41MR211 archeological deposits that suggest it was occupied after 1830:

- the presence of a refined earthenware sherd with a backmark dated from 1834-1836 (Parsons et al. 2002b:44);

- the presence of transfer-printed refined earthenware sherds with certain colors that only began to be used after the late 1820s (Parsons et al. 2002b:43);

- there are Redware sherds in the assemblage, which are found in East Texas sites that date as late as ca. 1850;

- the blue and green shell-edged vessel sherds at 41MR211 are of a style that was produced between ca. 1800 and 1840; green edging on vessels became rare after 1840;

- one of the green shell-edged sherds at 41MR211 has floral motifs (Parsons et al. 2002b:Figure 25d), and this embossed edge rim treatment was developed around 1825, and "remained popular well into the 1830s" (Hunter and Miller 2009:13);

- (f) sherds from "Lacy" pattern glass, in production from only as early as 1829 through the 1840 s (Parsons et al. 2002b:59);

- (g) a U.S. Military button with a stamped backmark that dates from 1827-1839 (Parsons et al. 2002b:66); and

- (h) gun parts (a flintlock gun cock and tumblers) from guns in use through the 1830s (Parsons et al. 2002b:71).

I think the reviewed archeological evidence is fairly unequivocal in indicating that 41MR211was occupied well into the 1830s. But, that being said, it does not change the main geographic arguments made by Tiller that this Jim's Bayou village is not Timber Hill or the last Caddo village in East Texas. The archeological evidence simply indicates that there were Caddos living north of the Sodo Lakes complex after 1830. There are other known archeological sites along James Bayou besides 41MR211 that hint at use of the locale by Caddo peoples as late as ca. 1835 (Perttula and Nelson 2010).

Tiller notes that the 1838-1839 land surveys suggest that the Jim's Bayou village was ca. $600 \mathrm{~m}$ in length, and that "this village, in terms of its physical size, is without parallel-likely a testament to its great age and historic importance" (Vol. III, p. 49). This is dubious. It is more likely to be the case that this "village" is comparable to many other ancestral Caddo settlements in that "villages" were comprised of a number of widely dispersed farmstead compounds-sometimes spread across many miles-rather than a nucleated settlement with a concentrated cluster of households. Under this scenario, the size of the Jim's Bayou village as estimated by the $19^{\text {th }}$ century land surveys is not of great note. As a final note on Ch. 3, it is interesting that $41 \mathrm{MR} 211$ by 
itself covers nowhere near ca. $600 \mathrm{~m}$ in length. Furthermore, its topographic location (see Perttula and Nelson 2010:Figure 3) falls well west (more than 0.5 miles) of the village plotting on the United States 1838 Plat Map as well as Tiller's general location plotting (Vol. III, Figure 1.4). This suggests there are other archeological components of the Jim's Bayou village that have yet to be discovered.

Part II in Vol. III concerns the history of the aftermath of the land cession on the Caddo Indian peoples. Tiller argues that there were a number of contributing factors that led to the July 1835 land cession, among them the U.S. government factory system and agencies, including the removal of services they had once provided to the native peoples who traded with the factories; the removal of Indian tribes from east of the Mississippi River to western lands; whiskey traders; removal of the Great Raft on the Red River; the encroachments of American and Mexican land squatters; and the difficulties of the Caddo Nation itself. These included the death of their caddi Dehahuit in March 1833, their increasing participation in the hide and fur trade, and their inability to support themselves through traditional agricultural practices. Once the United States and then Texas began expropriations of Caddo lands in East Texas and Northwest Louisiana, the Caddo peoples were harried and eventfully forcefully removed from their homelands within just the matter of a few years (1835-1838), and within a generation, the Caddo were gone from all of Texas.

Tiller continues the historical account with a consideration of the early post-land cession years (18351838), in particular the increasing pace of American land surveys, and the various movements and activities of the Caddo peoples, either in the borderlands or farther west in the Trinity and Brazos River prairies and crosstimbers. Texans did not trust the Caddo peoples, nor was there any reason for the Caddo to trust the intentions of Texans, who desired nothing more than the removal, however that could be accomplished, of all American Indians from the lands of the Republic of Texas. Tiller recounts the considerable difficulties the Caddo had in receiving their 1836-1838 annuities, and the fraudulent activities of their appointed annuity agents. In the end, the Caddo left their Harrison County villages in early 1838.

Chapter 6 in Vol. III details the little known history and travails of the Shreveport band of the Caddo, who came to the Shreveport area in the fall of 1838 to collect the 1838 annuity, where they remained (with little choice) until the spring of 1840, when they were removed to Choctaw Nation lands in Indian Territory in what is now the Fort Towson area of southeastern Oklahoma (Vol. III, p. 136). Then, along the Washita River in the Chickasaw District they were reunited in 1841 with some portion of the Caddo who had been living in the wilds of Texas, although other Caddo peoples chose to remain in Texas, until they too were removed to Indian Territory in 1859.

This third volume also contains 15 separate appendices and more than 35 pages of detailed endnotes. The appendices are various original source materials (correspondence and accounts, as well as a few ca. 18451852 maps) dating from 1834-1852 that Tiller drew upon in the body of Vol. III.

Tiller makes one unusual, but interesting comment in the Preface to Vol. III (p. x). In attending archeological conferences, he noted that he was struck "by the number of times in a single presentation [emphasis in the original] such qualifiers as "don't know for sure," "maybe," "perhaps" or "possibly" were used." This suggests that Tiller, as a geographer, may not have a full appreciation of the complexities of archeological science, or of the difficulties involved for archeologists in establishing beyond any reasonable doubt or with absolute certainty any specific set of archeological findings. Archeological findings are far from representing truths-either in measured time or geographic space-but rely on building a case for conclusions based on the preponderance of evidence from a diverse set of resources. And in fact, Tiller builds a similar set of conclusions using the historical record when it comes to making the case for the locations of early $19^{\text {th }}$ century Caddo villages in Northwest Louisiana and East Texas (Vol. III, pp. 10, 46, and 55). Hopefully, a concerted and well- 
planned archeological investigation of these villages can be developed and carried out in the years aheadperhaps as a collaborative effort with the Caddo Nation of Oklahoma-and archeological findings can also be brought to bear on Caddo native history during the early $19^{\text {th }}$ century in this part of the Caddo's ancestral lands.

In addition to a limited number of bound sets of Before the Lines, electronic versions of the three volumes are available from: The Director, Newton Gresham Library, Sam Houston State University, P.O. Box 2281 (1830 Bobby K Marks Drive), Huntsville, Texas, 77341 (936-294-1613). This three volume set contains a wealth of information about the early $19^{\text {th }}$ century Caddo settlement of East Texas and Northwest Louisiana, along with well-reasoned arguments about the place of these settlements, and I cannot recommend these books strongly enough to anyone interested in the history of the Caddo Indian peoples.

\section{References Cited}

Hunter, R. and G. L. Miller

2009 Suitable for Framing: Decorated Shell-Edge Earthenware. Early American Life, August 2009, pp. 8-19.

Parsons, M. L., J. Bruseth, J. Bagur, and C. McCrocklin

2002a Finding Sha'chahdinnih (Timber Hill): The Last Village of the Kadohadacho in the Caddo Homeland. Plains Anthropologist 47(182):231-249.

Parsons, M. L., J. E. Bruseth, J. Bagur, S. E. Goldborer, and C. McCrocklin

2002b Finding Sha'chahdinnih (Timber Hill): The Last Village of the Kadohadacho in the Caddo Homeland. Archeological Reports Series No. 3. Texas Historical Commission, Austin.

Perttula, T. K. and B. Nelson, with contributions by C. McCrocklin

2010 Archaeological Investigations Along James bayou in Marion County, Texas and Caddo Parish, Louisiana. Journal of Northeast Texas Archaeology 32:1-50.

Tiller, J.

2007 The Shreveport Caddo, 1835-1838. Journal of Northeast Texas Archaeology 26:159-167.

2008 Was Timber Hill the Last Caddo Village in the Caddo Homeland? Caddo Archeology Journal 18:1121.

2010 A Case for Dehahuit's Village, Part I. Caddo Archeology Journal 20:1-30.

2011 A Case for Dehahuit's Village, Part II. Caddo Archeology Journal 21:107-127.

2013 The Caddo Nation begins to Reassemble, 1840-1851. Caddo Archeology Journal 23:141-155.

Tiller, J. and G. Gong

2012 July 1, 1835: What did the Caddo Believe they were Selling, and was the Price Paid Fair? Caddo Archeology Journal 22:115-142. 